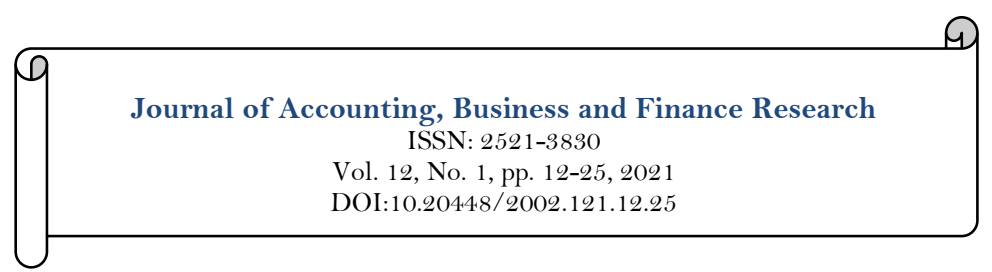

\title{
Determinants and Measurement Quality of the Financial Statements of Local Governments in Indonesia
}

\author{
Basyiruddin Nur ${ }^{1 *}$ \\ Roy Sembel $^{2}$ \\ Khomsiyah $^{3}$ \\ Juniati Gunawan ${ }^{4}$
}

'Doctoral Student in Accounting Studies, Faculty of Economics and Business, Trisakti University, Indonesia.

Email:nurbasyiruddin@gmail.com

${ }^{2}$ Professor and Distinguished Chair for Finance and Investment, IPMI International Business School, Indonesia.

${ }^{s, 4}$ Faculty of Economic and Business, Trisakti University, Indonesia.

\section{Abstract}

The aim of this research is to create a measurement index of the quality of the financial statements of local governments (FSLGs) using data from the accountability and performance reports on government entities (APRGEs), FSLG notes, and the internal control systems (ICS). The APRGEs have many indicators, but the relevant ones are the accounting information system (AIS), competence, performance, and good government governance (GGG). The measurement index sourced from the APRGEs is calculated from the percentage of performance achieved for every indicator. There are 35 main and seven conditional indicators taken from the FSLG notes. The ICS has 101 indicators. The sample comprises 25 local governments of provinces, cities and municipalities from 2015 to 2018 . EViews 8 was used for statistical computation. The output of the measurement index is the FSLG quality assessment category. The index can be used to measure the quality of FSLGs produced by local governments. The results of the statistical testing show that competence and GGG affect the quality of FSLGs, but AIS and performance do not. However, AIS and performance can still be used to measure the quality of FSLGs. AIS is a primary need that cannot be left out of the process of presenting FSLGs. Likewise for performance, each local government already has its own key performance indicators (KPIs) which will enable the civil state apparatus (CSA) to operate efficiently and follow the rules, including the preparation of FSLGs. The implication is to facilitate internal and external parties in assessing and improving the quality of financial statements of local governments.
Keywords:

Accounting information system Competence

Performance

Good government governance

The quality of financial statements of local governments.

Licensed:

This work is licensed under a

Creative Commons Attribution 4.0

License.

Publisher:

Scientific Publishing Institute

Received: 15 April 2021

Revised: 17 May 2021

Accepted: 11 June 2021

Published: 9 July 2021

( Corresponding Author)

Funding: This study received no specific financial support.

Competing Interests: The authors declare that they have no competing interests.

\section{Introduction}

Financial statements of local governments (FSLGs) describe the condition and financial performance of the entity. The quality of FSLGs is recognized after being audited by The Audit Board of the Republic of Indonesia. FSLGs were presented using a cash basis, then switched to a Cash Toward Accrual (CTA) basis from 2010 to 2014. The accrual basis was fully implemented in 2015. Several government agencies around the 
world do not use the accrual basis yet, even though they use Government Accounting Standards (GAS). The accrual basis requires a good accounting information system (AIS) with sufficient support for its applications, programs, and hardware (Efendi, Darwanis, \& Abdullah, 2017). Adequate competencies and good performance from each employee are also needed (Andini \& Yusrawati, 2015). In this case, good governance from the government is also necessary (Simon, Mas' ud, \& Su'un, 2016). However, the application of a good AIS does not always provide the best audit opinion. Likewise, the competence of a civil state apparatus (CSA) does not always provide a good audit opinion. Transparency in governance management has been implemented by performing the principles of good governance by some local governments. However, the audit opinion they received was not the best. This research aims to create a measurement index of the FSLGs using data from the Accountability and Performance Reports on Government Entities (APRGEs), FSLG notes, and their internal control system (ICS). The APRGEs provide information on the implementation of programs, activities, and policies to ensure the implementation of vision, missions, goals, and targets of local governments. COSO (2019) defines an ICS as:

"A process, effected by an entity's board of directors, management, and other personnel, designed to provide reasonable assurance regarding the achievement of objectives relating to operations, reporting, and compliance."

An ICS is essential in producing quality FSLGs. The creation of the measurement index of the quality of FSLGs is proposed for ease of measurement and as an alternative measurement tool.

\section{Literature Review}

2.1. Agency Theory

In this research, the agency theory was used to explain the phenomenon of the presentation of FSLGs for reporting and responsibility obligations of the management of local government to the public. Empirically, local governments tend to provide asymmetric information based on their interests, which means that the public interest is not fulfilled (Pandansari, 2016). Jensen and Meckling (1976) defined an agency relationship as "a contract under which one or more persons (the principal(s)) engage another person (the agent) to perform some service on their behalf which involves delegating some decision-making authority to the agent".

This study uses agency theory because the government as the agent and the society as the principal requires an accountability report from the agent, which must be submitted and explained by the government. The government as an agent also has a responsibility to provide valuable information for users of FSLGs.

\subsection{Accountability and Performance Reports on Government Entities (APRGE)}

There are many indicators in APRGEs, but the relevant ones are AIS, competence, performance, and GGG. The goal of the APRGE presentation is the highest grade of APRGE submitted by the Ministry of Administrative and Bureaucratic Reform of the Republic of Indonesia. The review method to determine the grade of APRGE is by summarizing the final calculation of each component's grade. Then, the outcome of summarized figures will be recognized as the final grade of the APRGE. The final value is used to determine the level of accountability of the local government relating to its performance.

\subsection{Accounting Information System (AIS)}

AIS technology is an important tool in preparing FSLGs. The benchmarks used to measure the AIS are the improvement in the quality of regional financial management and the realization of a local government based on information and communication technology (ICT).

\subsection{Competence}

Spencer and Signe (1993) stated that:

"A competency is an underlying characteristic of an individual that is causally related to criterion referenced effective and/or superior performance in a job or situation".

\subsection{Good Government Governance (GGG)}

The United Nations Development Programme (2015) issued by the UN System Task Team on The Post-2015 UN Development Agenda 2012 defines GGG as follows:

"Governance is the exercise of economic, political and administrative authorities to manage a country's affairs at all levels. It comprises mechanisms, processes and institutions, through which citizens and groups articulate their interests, exercise their legal rights, meet their obligations and mediate their differences. Governance has "three legs": economic, political and administrative. Economic governance includes decision-making processes that affect a country's economic activities and its relationships with other economies. Political governance is the process of decision making to formulate policy. Administrative governance is the system of policy implementation".

\subsection{Performance}

FSLGs describe local governments' performance for interested parties. Good local government performance is obtained through the cooperation of all elements, both from higher-level management and the lower-level staff who prepare FSLGs. 
2.7. The Quality of FSLGs

Good quality FSLGs must be submitted in a reliable, relevant, trustworthy, and understandable presentation. To obtain quality FSLGs, supporting factors such as competence and AIS are needed.

\subsection{Accrual Basis}

The application of the accrual-based accounting system has several stages, starting from the cash basis in 2005 and earlier, then the Cash Toward Accrual (CTA), which was fully implemented in 2015. The application of accrual-based accounting is set out under the accrual-based Government Accounting Standards (GAS).

\subsection{The Measurement Index of FSLGs}

In this research, the other quality measurement methods of FSLGs will be added. The measurement tool used the data from the APRGE and FSLG notes. The measurement index of the quality of FSLGs, sourced from APRGEs, is calculated from the percentage of performance achievement of every indicator for each variable (AIS, competence, performance, and GGG).

Table 1. APRGE Measurement Index.

\begin{tabular}{|c|c|}
\hline No. & Indicator \\
\hline & I. Accounting information system \\
\hline 1 & Increased quality of regional financial management. \\
\hline 2 & The establishment of government-based information \& communication technology. \\
\hline 3 & Increased public access to information \& communication systems. \\
\hline 4 & The establishment of e-government regulations. \\
\hline 5 & The increase of internet-based public services. \\
\hline \multirow[t]{2}{*}{6} & The development of management information systems. \\
\hline & II. Competence \\
\hline 1 & $\begin{array}{l}\text { The increase of the professionalism of the examining apparatus and the invention of bureaucratic } \\
\text { transparency. }\end{array}$ \\
\hline 2 & The increasing number of supervisory employees participating in training. \\
\hline 3 & $\begin{array}{l}\text { The realization of competent, competitive, trustworthy, professional, and responsible government } \\
\text { employees. }\end{array}$ \\
\hline 4 & The increasing number of staff who have completed bachelor's and master's degrees. \\
\hline 5 & The increasing level of clean government. \\
\hline 6 & The realization of a disciplined and integrated apparatus. \\
\hline \multirow[t]{2}{*}{7} & The decreasing amount of undisciplined civil servants. \\
\hline & III. Performance \\
\hline 1 & The increasing quality and productivity of the workforce. \\
\hline 2 & The increasing number of civil state apparatus employees who receive competency-based training. \\
\hline 3 & The increasing quality of financial reports. \\
\hline 4 & The increasing value and predicate of accountability performance of government agencies. \\
\hline 5 & The results of the audit board's opinion. \\
\hline 6 & The increasing number of certified auditors. \\
\hline 7 & The implementation of local governments' accountability and bureaucracy. \\
\hline \multirow[t]{2}{*}{8} & $\begin{array}{l}\text { The fulfillment of minimum service standards and standard operating procedures by each local } \\
\text { government agency. }\end{array}$ \\
\hline & IV. Good government governance \\
\hline 1 & Improved performance of governance and cooperation between regions. \\
\hline 2 & The increase of transparency and public accountability. \\
\hline 3 & $\begin{array}{l}\text { The increasing percentage of government institutions \& management to achieve efficiency \& } \\
\text { effectiveness in local government administration. }\end{array}$ \\
\hline 4 & The increasing value of APRGEs. \\
\hline 5 & The improvement of effective and efficient governance. \\
\hline
\end{tabular}

Table 1 contains the measurement index sourced from APRGEs. The index contains indicators used to measure the independent variables of AIS, competence, performance, and GGG.

Table 2 contains 35 main indicators sourced from the FSLG notes, while Table 3 contains the seven conditional indicators sourced from the FSLG notes. 
Table 2. Main Indicators.

\begin{tabular}{|c|c|}
\hline No. & Main indicator \\
\hline 1 & General information and description of the entity. \\
\hline 2 & $\begin{array}{l}\text { The description of the reporting entity: domicile, legal form, jurisdiction, main activities of } \\
\text { operation, and the operational basis according to the regulations. }\end{array}$ \\
\hline 3 & Realization and financial position of the reporting entity in its entirety. \\
\hline 4 & Realization of progress and the financial/fiscal position of the reporting entity. \\
\hline 5 & $\begin{array}{l}\text { The reporting entity presents information about the differences in realization and financial/fiscal } \\
\text { positions for the current and previous periods. }\end{array}$ \\
\hline 6 & $\begin{array}{l}\text { Government policies regarding raising income, spending efficiency, and selecting resources or } \\
\text { finance management. }\end{array}$ \\
\hline 7 & Macroeconomic disclosure. \\
\hline 8 & Budget changes in the current and prior periods. \\
\hline 9 & Reporting entities follow the budget conditions and developments. \\
\hline 10 & The comparison between the target and the realization of state/local government budgets. \\
\hline 11 & $\begin{array}{l}\text { General description of the government's financial performance in realizing potential revenue on } \\
\text { Budget Realization Reports and expenditure allocations that have been determined in the } \\
\text { state/local government budgets. }\end{array}$ \\
\hline 12 & $\begin{array}{l}\text { The structure of revenue in the Budget Realization Report and the reasons for the difference } \\
\text { between the target and the realization. }\end{array}$ \\
\hline 13 & The basis for the presentation of financial statements and accounting policies. \\
\hline 14 & Basic assumptions or concepts of accounting for the preparation of financial statements. \\
\hline 15 & $\begin{array}{l}\text { The basic assumptions for financial reporting are the assumptions of an independent entity, the } \\
\text { entity's sustainability, and measurability in terms of money. }\end{array}$ \\
\hline 16 & The government does not liquidate the reporting entities in the short term. \\
\hline 17 & The financial statement presents the activities that can be valued in terms of money. \\
\hline 18 & $\begin{array}{l}\text { The users of FSLGs are the public, people's representatives, supervisory agencies, auditing } \\
\text { institutions, and parties who are involved in donations, investments, and loans. }\end{array}$ \\
\hline 19 & The selected accounting policies on preparing financial statements. \\
\hline 20 & The accounting policies are customized to the conditions of the reporting entity. \\
\hline 21 & $\begin{array}{l}\text { Accounting policies and preparation of financial statements are based on sound judgment, } \\
\text { removing uncertainty regarding transactions, substance over form, and materiality. }\end{array}$ \\
\hline 22 & $\begin{array}{l}\text { The accounting principles and methods of their application affect the presentation of the Budget } \\
\text { Realization Report, the Changes in the Excess Budget Balance, the Balance Sheet, the Operational } \\
\text { Report, the Cash Flow Statement, and Report on Changes in Equity. }\end{array}$ \\
\hline 23 & $\begin{array}{l}\text { Accounting policies regarding reporting entities, basic accounting principles, measurement bases, } \\
\text { and accounting policies relating to Government Accounting Standards. }\end{array}$ \\
\hline 24 & Basic accounting principles. \\
\hline 25 & Measurement based on the presentation of financial statements. \\
\hline 26 & $\begin{array}{l}\text { Accounting policies in terms of revenue recognition in the Budget Realization Reports and } \\
\text { Operational Reports; expenditure and expense recognition; consolidation report preparation } \\
\text { principles; investment; recognition and termination/write-off of tangible and intangible assets; } \\
\text { construction contracts; partnerships with third parties; research costs; development, supply and } \\
\text { formation of reserve funds; the establishment of employee welfare funds; and foreign currency } \\
\text { interpretation. }\end{array}$ \\
\hline 27 & $\begin{array}{l}\text { The financial statements show the correlation between the current numbers and those of the } \\
\text { previous period. }\end{array}$ \\
\hline 28 & $\begin{array}{l}\text { Details and explanations are given for each item in the Budget Realization Report, Changes in } \\
\text { Budget Balance Report, Balance Sheet, Operational Report, Cash Flow Statement, and Changes in } \\
\text { Equity Report. }\end{array}$ \\
\hline 29 & The explanation of the post revenue Budget Realization Report, expenditure, and financing. \\
\hline 30 & Explanation of the Changes in Budget Balance Reports. \\
\hline 31 & The explanation of income-related Operational Reports and expenses. \\
\hline 32 & The description of the balance sheet for assets, liabilities, and equity. \\
\hline 33 & $\begin{array}{l}\text { The explanation of the cash flow statement for operating activities, investing in non-financial } \\
\text { assets, financing activities, and non-budgeting activities. }\end{array}$ \\
\hline 34 & $\begin{array}{l}\text { Explanation of the Statement of Changes in Equity at the beginning of the period, surplus/deficit- } \\
\text { related Operational Statement, the cumulative impact of changes in policy/fundamental errors, } \\
\text { and equity at the end of the period. }\end{array}$ \\
\hline 35 & FSLG notes do not duplicate the account details. \\
\hline
\end{tabular}


Table 3. Conditional Indicators

\begin{tabular}{|c|c|}
\hline \multicolumn{2}{|r|}{ Conditional indicators } \\
\hline 1 & $\begin{array}{l}\text { The description of issues that affect the financial condition of the reporting entity in a future } \\
\text { period. }\end{array}$ \\
\hline 2 & $\begin{array}{l}\text { Significant events during the reporting year, such as changes in government management, } \\
\text { previous mismanagement, commitments or contingencies that cannot be presented on the } \\
\text { financial statements balance sheet, the merging or expansion of entities for the current year, and } \\
\text { events that have a social impact, for example, strikes that the government must overcome. }\end{array}$ \\
\hline 3 & $\begin{array}{l}\text { Changes in accounting policies that are not material in the same year should be disclosed if they } \\
\text { have a material effect on the following year. }\end{array}$ \\
\hline 4 & Considering the types of activities and policies to be disclosed in the FSLG notes. \\
\hline 5 & The reporting entities provide other financial information. \\
\hline 6 & $\begin{array}{l}\text { The responsibility for managing assets and resources off the balance sheet, including loss or } \\
\text { damage of assets and resources. }\end{array}$ \\
\hline 7 & Unregulated accounting standards must be revealed. \\
\hline
\end{tabular}

The measurement scale that enables ease of interpretation of target achievements in the measurement index developed by the researchers is described in Table 4 as follows:

Table 4. Value Category for the Measurement Index of the Quality of FSLG.

\begin{tabular}{c|c|c|l}
\hline No. & Category & $\begin{array}{c}\text { Number } \\
\text { value } \%\end{array}$ & Interpretation \\
\hline 1 & A & $\geq 100$ & Satisfactory (Qualified) \\
\hline 2 & B & $>90-99$ & $\begin{array}{l}\text { Good (Not qualified, but still classified as good and adequately adheres to } \\
\text { GAS) }\end{array}$ \\
\hline 3 & C & $>80-90$ & Enough (Not qualified but still sufficient to comply with GAS) \\
\hline 4 & D & $>70-80$ & $\begin{array}{l}\text { Bad (The FSLG does not qualify because it does not fulfil the required GAS } \\
\text { disclosures) }\end{array}$ \\
\hline 5 & E & $<70$ & Poor (The FSLG notes are inadequate) \\
\hline
\end{tabular}

Table 4 describes the value categories for the measurement index of the quality of FSLGs. Category A with a value range $\geq 100 \%$ is interpreted as Satisfactory. Category B with a value range of 90-99\% is interpreted as good quality. Category $\mathrm{C}$ with a value range of $80-90 \%$ is interpreted as enough. Category $\mathrm{D}$ with a value range of $70-80 \%$ is interpreted as bad quality. Category $\mathrm{E}$ with values $<70 \%$ is interpreted as poor quality. Furthermore, Internal Control System (ICS) will be added as an indicator for measuring the quality of FSLG in the notes.

To measure the ICS, questionnaires were drawn up. Nowadays, local governments do not produce ICS reports which would have been submitted in the FSLG notes. Table 5 contains 101 indicators for ICS derived from the elements of internal control (Control Environment, Risk Assessment, Control Activity, Information and Communication, and Monitoring).

Table 5. ICS Indicators.

\begin{tabular}{|c|c|}
\hline \multicolumn{2}{|c|}{ Internal control system (ICS) } \\
\hline \multicolumn{2}{|c|}{ Element: Control environment } \\
\hline \multicolumn{2}{|r|}{ Integrity and ethical values } \\
\hline 1 & $\begin{array}{l}\text { There are written internal policies or rules on behavior that explain the sanctions for fraud or } \\
\text { dishonesty established by the administration (a code of ethics and penalties for violations). }\end{array}$ \\
\hline 2 & The policies or rules have been communicated to all employees. \\
\hline 3 & $\begin{array}{l}\text { Employees have signed a written statement agreeing to adhere to the code of conduct (e.g., an } \\
\text { integrity pact such as the Regulation of the Minister for Empowerment of State Apparatus and } \\
\text { Bureaucratic Reform number } 60,2012) \text {. }\end{array}$ \\
\hline 4 & $\begin{array}{l}\text { There is a special unit within the local government that enforces rules regarding employee } \\
\text { behavior. }\end{array}$ \\
\hline 5 & Employees who break rules or policies are sanctioned by the supervisor accordingly. \\
\hline 6 & $\begin{array}{l}\text { The penalties for violations have been communicated to all employees so that they are aware of } \\
\text { the consequences of deviations and offenses committed. }\end{array}$ \\
\hline 7 & $\begin{array}{l}\text { There are formal procedures for setting out, changing, or eliminating a control in the local } \\
\text { government environment. }\end{array}$ \\
\hline \multicolumn{2}{|r|}{ Commitment to competence } \\
\hline 8 & $\begin{array}{l}\text { The local government determines the qualifications or requirements of education, the } \\
\text { knowledge, and skill that must be met to occupy or perform certain duties (competence } \\
\text { standards for each office and duty executive). }\end{array}$ \\
\hline 9 & Employees who were to occupy a particular office or committee were appropriately tested. \\
\hline
\end{tabular}




\begin{tabular}{|c|c|}
\hline 10 & $\begin{array}{l}\text { There are efforts made by local governments to improve employee knowledge and skills } \\
\text { through training or courses. }\end{array}$ \\
\hline 11 & $\begin{array}{l}\text { There are training or courses conducted by governments according to the needs of employees } \\
\text { or the job requirements. }\end{array}$ \\
\hline 12 & $\begin{array}{l}\text { There are formal or informal programs with guidelines for new employee orientation and } \\
\text { training. }\end{array}$ \\
\hline 13 & $\begin{array}{l}\text { Local government employees have the required competence levels according to the standards of } \\
\text { competence set out for each department (e.g., the financial statements arranger has an education } \\
\text { background in accounting). }\end{array}$ \\
\hline 14 & $\begin{array}{l}\text { The continuation of staff education receives support from the local government (there is a } \\
\text { scholarship and training for qualified workers). }\end{array}$ \\
\hline 15 & Each employee receives ongoing education and training according to their roles and capacities. \\
\hline 16 & $\begin{array}{l}\text { There is a monitoring mechanism in place to ensure that every employee receives technical } \\
\text { training according to their field of work. }\end{array}$ \\
\hline 17 & Employees must complete a minimum number of hours of training. \\
\hline \multicolumn{2}{|r|}{ Management philosophy and operating style } \\
\hline 18 & $\begin{array}{l}\text { The regional leaders make regular reports on the progress of program implementation and } \\
\text { activities to be submitted to the local government. }\end{array}$ \\
\hline 19 & The report contains the target timelines, obstacles, and achievements of programs and activities. \\
\hline 20 & $\begin{array}{l}\text { The Regional Head holds regular meetings with all other Regional Heads to evaluate the } \\
\text { achievement of programs and activities based on reports from each unit leader. }\end{array}$ \\
\hline 21 & Any decisions made by the chairman are discussed with the subordinate(s). \\
\hline 22 & $\begin{array}{l}\text { The local government is involved in designing changes in the control structure: } \\
\text { - Controls are adequately monitored } \\
\text { - There are follow-up actions on deviations from the applicable control elements. }\end{array}$ \\
\hline 23 & $\begin{array}{l}\text { The regional unit leaders implement standard procedures for each process and require } \\
\text { employees to follow these procedures. }\end{array}$ \\
\hline 24 & $\begin{array}{l}\text { The local government is willing to accept advice from competent parties regarding important } \\
\text { matters related to accounting and internal control issues. }\end{array}$ \\
\hline 25 & $\begin{array}{l}\text { The local government has a sense of responsibility for its financial statements, emphasizing the } \\
\text { importance of the accuracy of accounting data and generally accepted accounting methods as } \\
\text { well as the obligation to carry out routine reconciliations between related accounting units (for } \\
\text { example, the Regional General Treasurer with the Expenditure Treasurer, or the Accounting } \\
\text { Sector or the Asset Sector with the Regional Work Unit Goods Manager). }\end{array}$ \\
\hline 26 & $\begin{array}{l}\text { No one leader in the local government environment is dominant compared to other leaders, so } \\
\text { the checks and balances between the leaders are adequate. }\end{array}$ \\
\hline 27 & $\begin{array}{l}\text { There are indications that the Regional Head and his staff: } \\
\text { - Want fair financial statements } \\
\text { - Are honest in responding to auditor's questions } \\
\text { - Are conscientious in making accounting estimates } \\
\text { - Have integrity } \\
\text { - Have a strong sense of control. }\end{array}$ \\
\hline 28 & The Regional Head makes improvements/adjustments to the regional unit leaders. \\
\hline 29 & $\begin{array}{l}\text { There is a written policy regarding the pattern of transfer, rotation, and promotion of } \\
\text { employees. }\end{array}$ \\
\hline \multicolumn{2}{|r|}{ Organizational structure } \\
\hline 30 & The organizational structure is determined by regional regulations. \\
\hline 31 & $\begin{array}{l}\text { The organizational structure describes the main tasks, functions, responsibilities, and } \\
\text { authorities for each work unit. }\end{array}$ \\
\hline 32 & $\begin{array}{l}\text { The organizational structure provides an adequate overall framework for planning, directing, } \\
\text { monitoring, and facilitating the sufficient flow of information. }\end{array}$ \\
\hline 33 & $\begin{array}{l}\text { There are adjustments to changes in the organizational structure related to changes in laws and } \\
\text { regulations and the strategic environment. }\end{array}$ \\
\hline 34 & $\begin{array}{l}\text { There is a job analysis to determine the number of employees needed for each unit within the } \\
\text { local government organization. }\end{array}$ \\
\hline \multicolumn{2}{|c|}{ Delegation of authority and responsibility } \\
\hline 35 & $\begin{array}{l}\text { Job descriptions are set by superiors for each employee, especially for employees who are } \\
\text { responsible for managing regional budgets and assets. }\end{array}$ \\
\hline 36 & $\begin{array}{l}\text { The policies and procedures set by the management for each task have been stated in writing so } \\
\text { that the employees are aware of the authorities and responsibilities, especially procedures } \\
\text { related to budget management (there are standard operating procedures in every budget }\end{array}$ \\
\hline
\end{tabular}




\begin{tabular}{|c|c|}
\hline & management procedure from planning to reporting). \\
\hline 37 & Employees who do not carry out their duties and responsibilities will be penalized. \\
\hline 38 & $\begin{array}{l}\text { Delegation of tasks and authority is given to employees who can realize the main goals and } \\
\text { functions of the work unit. }\end{array}$ \\
\hline 39 & $\begin{array}{l}\text { The capacity for delegation of authority is well regulated so the division of tasks is fairly even } \\
\text { among employees. }\end{array}$ \\
\hline \multicolumn{2}{|r|}{ Policies and practices related to human resources } \\
\hline 40 & $\begin{array}{l}\text { The local government has employee competency standards that include background knowledge, } \\
\text { skills and education for each position as the basis for recruiting new employees. }\end{array}$ \\
\hline 41 & $\begin{array}{l}\text { Employees who are recruited or accepted have matched their background knowledge, skills, and } \\
\text { education with the required qualifications. }\end{array}$ \\
\hline 42 & $\begin{array}{l}\text { Employees are placed in work units that fit with their educational background and technical } \\
\text { competencies (for example, employees with accounting education backgrounds are placed in } \\
\text { organizational units that prepare financial statements). }\end{array}$ \\
\hline 43 & Employee promotion is based on work performance, rank, and seniority. \\
\hline 44 & $\begin{array}{l}\text { There is an adequate employee performance appraisal mechanism in addition to the DP3 which } \\
\text { is carried out at the end of the year. }\end{array}$ \\
\hline 45 & $\begin{array}{l}\text { Each employee transfer considers the technical ability of the employee with the technical needs } \\
\text { of the work unit. }\end{array}$ \\
\hline 46 & $\begin{array}{l}\text { The local government implements a reward and punishment system for achieving employee } \\
\text { performance. }\end{array}$ \\
\hline 47 & $\begin{array}{l}\text { There is an employee transfer policy within the bureau/finance section (tasks are rotated } \\
\text { periodically among employees). }\end{array}$ \\
\hline \multicolumn{2}{|r|}{ Element: Risk assessment } \\
\hline 48 & $\begin{array}{l}\text { The local government has identified risks that may hinder the preparation of regional financial } \\
\text { reports, such as late submission of accountability letters. }\end{array}$ \\
\hline 49 & $\begin{array}{l}\text { The local government has anticipated changes in regulations and accounting standards related } \\
\text { to the recording and reporting process. }\end{array}$ \\
\hline 50 & $\begin{array}{l}\text { The local government has anticipated weaknesses in the use of information technology in } \\
\text { transaction processing, such as backing up data if data stored on a computer is lost, or program } \\
\text { bottlenecks. }\end{array}$ \\
\hline 51 & $\begin{array}{l}\text { The local government has anticipated changes in personnel by transferring employees where } \\
\text { applicable within the bureau/finance division or the work unit in charge of finance and } \\
\text { bookkeeping. }\end{array}$ \\
\hline 52 & $\begin{array}{l}\text { The local government has anticipated the possibility of collusion between employees who are } \\
\text { family members. Employees who have relatives who are members of staff are not placed in } \\
\text { units/positions that have a strategic relationship. }\end{array}$ \\
\hline 53 & $\begin{array}{l}\text { Cash withdrawal is handled by the cash holder/treasurer periodically and suddenly by the } \\
\text { internal audit function. }\end{array}$ \\
\hline 54 & $\begin{array}{l}\text { There is a new or improved system (information technology) that has been implemented by the } \\
\text { regional government in processing financial transactions. }\end{array}$ \\
\hline 55 & $\begin{array}{l}\text { All of the systems (information technology) created or selected have been tested before being } \\
\text { applied in processing transaction data. }\end{array}$ \\
\hline 56 & The employee turnover rate is quite high in bookkeeping and finance. \\
\hline 57 & There is pressure on employees to immediately complete financial reports in too short a time. \\
\hline \multicolumn{2}{|r|}{ Element: Control activity } \\
\hline \multicolumn{2}{|r|}{ Information processing controls } \\
\hline 58 & $\begin{array}{l}\text { The signing of payment orders, checks, disbursement orders or other documents is only carried } \\
\text { out by personnel who have been appointed in the Decree of the Regional Head. }\end{array}$ \\
\hline 59 & $\begin{array}{l}\text { Payment orders, checks, disbursement orders, or other important documents are verified before } \\
\text { being signed by the designated personnel. }\end{array}$ \\
\hline 60 & $\begin{array}{l}\text { Payment orders, checks, disbursement orders, and other important documents that are not used } \\
\text { are stored in a safe place. }\end{array}$ \\
\hline 61 & $\begin{array}{l}\text { There are prenumbered serial numbers on payment orders, checks, disbursement orders, and } \\
\text { other forms/documents. }\end{array}$ \\
\hline 62 & $\begin{array}{l}\text { There is a reconciliation between regional treasury accounts, cash in the expense treasury and } \\
\text { cash in the receipt treasury, with periodic and routine checks of accounting records, receipts and } \\
\text { expenses. }\end{array}$ \\
\hline 63 & There is periodic matching between the general ledger and the subsidiary ledgers. \\
\hline
\end{tabular}




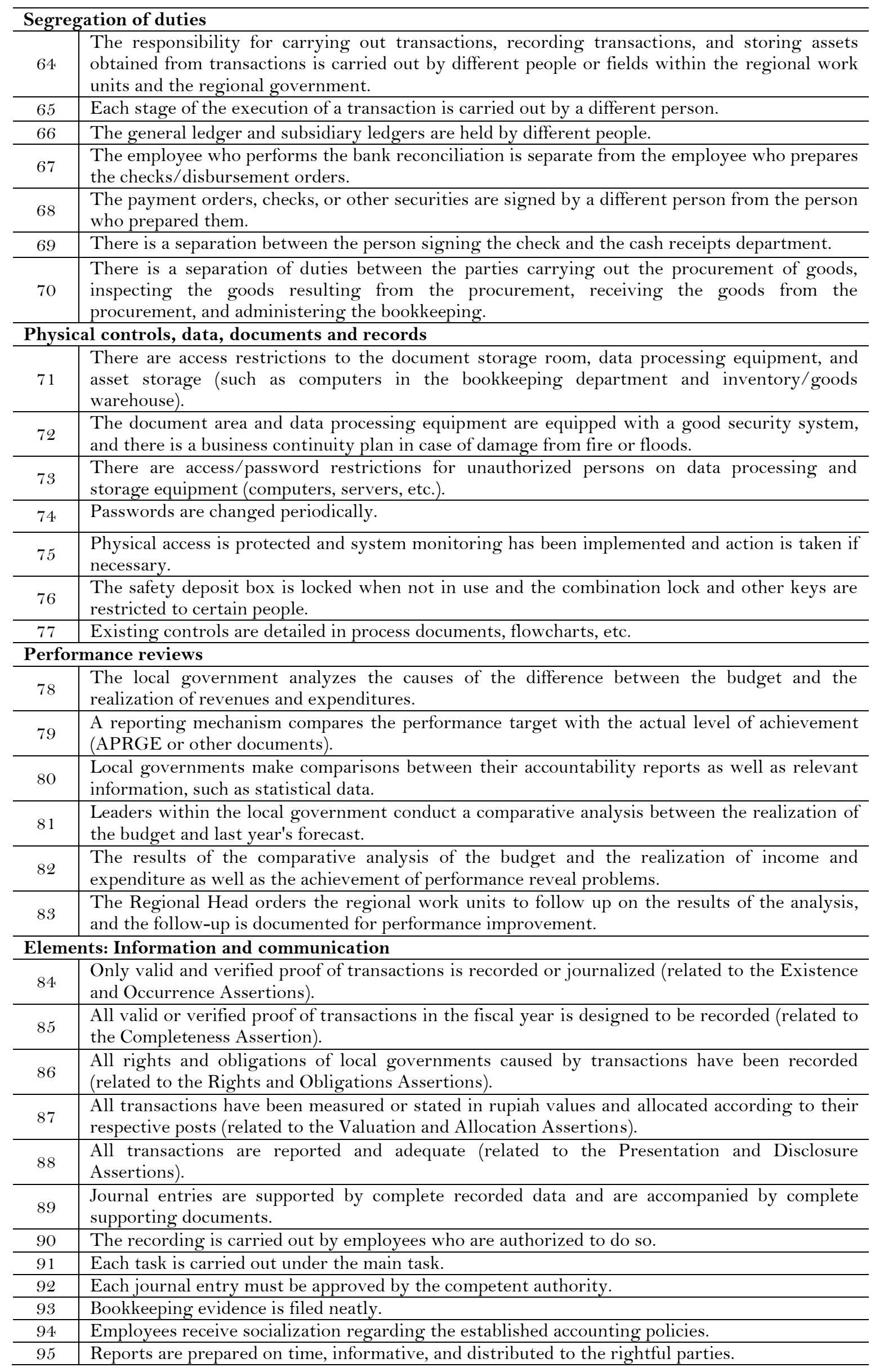




\begin{tabular}{c|l}
\hline 96 & $\begin{array}{l}\text { There is an integrated information system that allows the practice of financial decentralization } \\
\text { to be monitored centrally (the information systems between regional work units and regional } \\
\text { Financial Management units are integrated). }\end{array}$ \\
\hline Element: Monitoring \\
\hline 97 & $\begin{array}{l}\text { Every recommendation to improve the Internal Control Structure submitted by the Internal } \\
\text { Auditor and External Auditor has been implemented and monitored by the DPRD. }\end{array}$ \\
\hline 98 & The audit findings have been followed up as a whole. \\
\hline 99 & $\begin{array}{l}\text { Public complaints or issues in the mass media receive attention from the regional government } \\
\text { and the regional people's representative council and are followed up by the authorized regional } \\
\text { work units. }\end{array}$ \\
\hline 100 & $\begin{array}{l}\text { The division of tasks and authority is properly monitored. } \\
\text { The leader periodically receives reports on the status of the completion of recommendations } \\
\text { submitted by internal and external auditors to ensure the quality and timeliness of the } \\
\text { completion of each recommendation. }\end{array}$ \\
\hline
\end{tabular}

2.10. Research Hypotheses

$H_{I}$ : The accounting information system (AIS) has a positive effect on the quality of FSLGs.

Regional financial accounting information systems are capable of handling regional financial management processes, from budget preparation to regional financial reporting (Sihasale \& Setiyowati, 2018). Efendi et al. (2017) stated that the application of an AIS will result in faster transaction processing and the calculations will have a higher degree of accuracy, which will lead to an increase in the quality and reliability of FSLGs. Gafur, Yusuf, and Lamaya (2016) stated that the regional financial AIS also has a very important role in making decisions. The AIS is a resource designed to submit all the data for decision making. Efendi et al. (2017); Sihasale and Setiyowati (2018) and Gafur et al. (2016) stated that that the AIS has a positive effect on the quality of FSLGs.

\section{$H_{2}$ : Competence has a positive effect on the quality of FSLGs.}

A competent human resources (HR) department will be able to understand accounting logic. This must be supported by a background in accounting education and experience in finance, often attending tutoring and completing training (Kurniawan, 2016). Competence to carry out their duties and responsibilities with adequate experience, training and education can help employees complete the work assigned to them. This can support local governments in producing reliable FSLGs (Efendi et al., 2017). The more competent human resources are, the higher the quality of FSLGs. If the competence of human resources is low, it will result in less qualified FSLGs (Wibawa, Sinarwati, \& Yuniarta, 2017). Wibawa et al. (2017); Kurniawan (2016) and Efendi et al. (2017) showed that competence has a positive effect on the quality of FSLGs.

\section{$H_{s}$ : The accounting information system (AIS) has a positive effect on performance.}

The application of AIS starts by grouping, classifying, recording and processing government financial activities into a financial report to produce accurate information. The existence of technology-based tools, namely AIS, will make it easier to prepare financial reports. The government's performance will be reflected in how civil state employees in local government agencies produce timely financial reports using the AIS (Armel, Nasir, \& Safitri, 2017).

\section{$H_{4:}$ Competence has a positive effect on performance.}

Human resource competence in terms of quality and quantity can increase the value of the information contained in FSLGs. Employee competence must always be sharpened and improved to ensure effective performance. Competence is very important in supporting the quality of civil state apparatus (CSA) in carrying out their field of work. The suitability between the competence of the apparatus and their field of work will help the civil state apparatus employees understand their work properly.

Hanifa, Wawo, and Husin (2016) and Inapty and Martiningsih (2016) stated that competence has a positive effect on performance.

\section{$H_{5:}$ Performance has a positive effect on the quality of FSLGs.}

The performance of an apparatus is very important in supporting local government agencies toward financial management. This is because the performance of the apparatus is also very influential on the quality of FSLGs. Zarlin and Khairani (2017) stated that the performance of an apparatus has a positive effect on the quality of FSLGs.

$H_{6}$ : The accounting information system (AIS) has a positive effect on the quality of FSLGs, with good government governance (GGG) as a moderating variable.

AIS must also be supported by GGG so that the information made available to users can provide benefits and help in making decisions for users of FSLGs. When the GGG is excellent, will affect the government's 
AIS. Sihasale and Setiyowati (2018) and Untary and Ardiyanto (2015) stated that AIS has a positive effect on the quality of FSLGs. Moreover, Kewo and Rufaedah (2019) stated that GGG has a positive effect on the quality of FSLGs.

$H_{7}$ : Competence has a positive effect on the quality of FSLGs, with good government governance (GGG) as a moderating variable.

In excellent regional financial management, local government agencies must have competent human resources. It is believed that competent human resources can affect the quality of FSLGs. In addition to GGG, the competence of the apparatus will be properly channeled according to its field and will be able to produce quality FSLGs. Wibawa et al. (2017) and Andini and Yusrawati (2015) stated that competence has a positive effect on the quality of FSLGs. Moreover, Oktarina (2016) stated that competence and GGG have a positive effect on the quality of FSLGs.

\subsection{Framework}

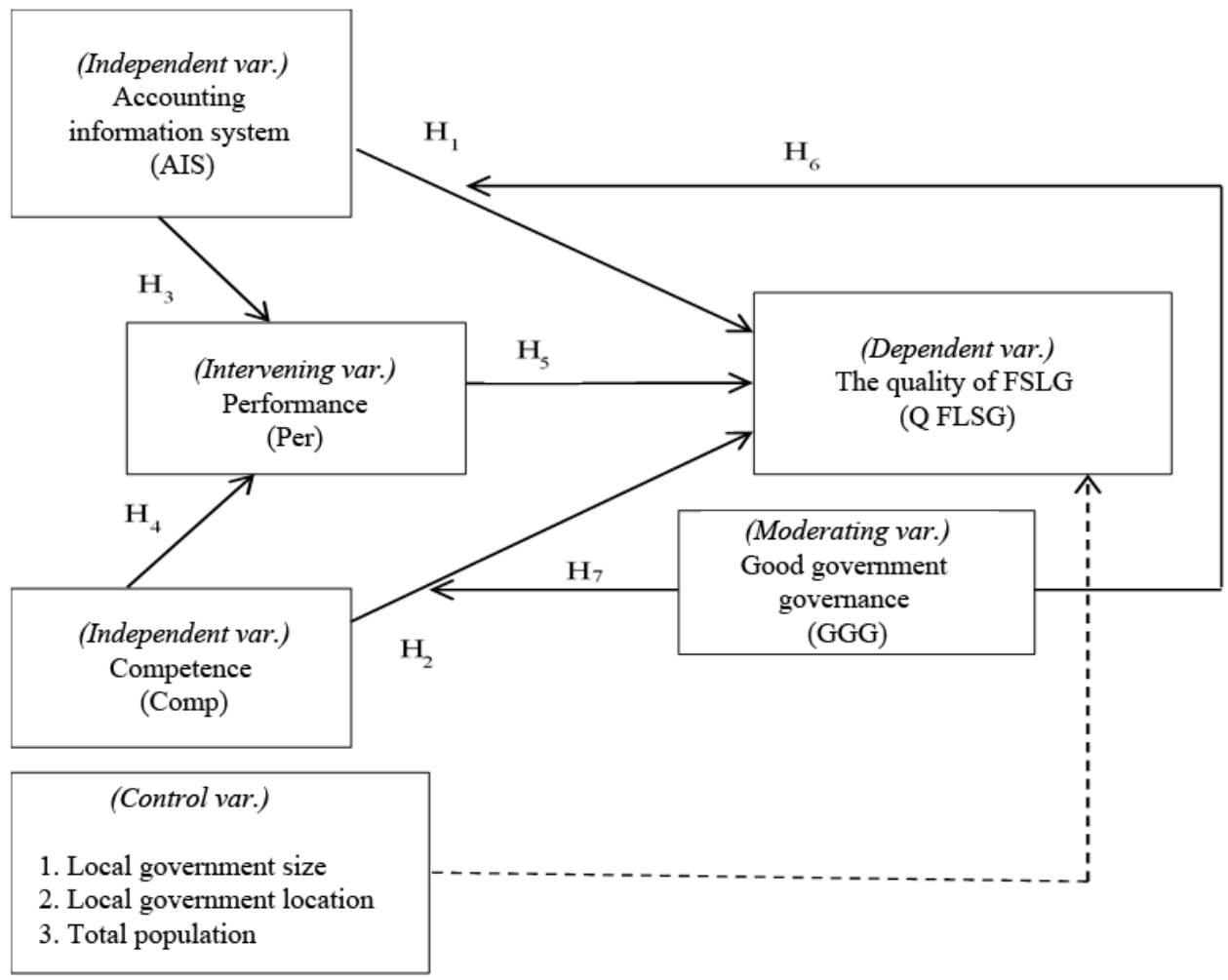

Figure 1. Framework.

The framework shown in Figure 1 explains the relationship between the variables of AIS, competence, performance and GGG, with the quality of FSLG and the control variables used, namely local government size, local government location, and total population.

\section{Research Method}

\subsection{Sample Selection and Data Collection}

The data population in this research comprises 25 local governments of provinces, cities, and municipals with a period of research four years, from 2015 to 2018. This research uses panel data, which is a combination of cross-sectional and time-series data. EViews 8 was used for statistical computation.

\subsection{Measurement of Study Variables}

3.2.1. Independent Variables

The independent variables in this study are accounting information systems, competence, performance, and good government governance and they are measured using indicators sourced from APRGEs. In conducting the assessment, the percentage of the performance achievement figures are totaled for all indicators of each variable and the average value is used. 


\subsubsection{Dependent Variables}

The indicators of the quality of FSLGs comprise 35 main and seven conditional indicators. The presence of the main indicators is given a value of " 1 ", and " 0 " otherwise. Meanwhile, the presence of conditional indicators will be given a score of 0.5 , and its absence does not affect the calculation of the measurement of quality.

\subsubsection{Control Variables}

In this study, the three control variables are local government location, local government size, and total population, and these were used to test the effect of the independent variables on the dependent variables. These variables were chosen as control variables due to the availability of quantified data that could be used in statistical calculations. Suhardjanto and Yulianingtyas (2010) found that local governments in Java tend to comply with Government Accounting Standards (GAS). The size of the local government in this study is proxied by using total assets, which is based on the research of Putri and Arza (2015) and Waliyyani and Makhmud (2015). A larger population in one territory will encourage the need more disclosure of FSLGs (Hendriyani \& Tahar, 2015).

(Size $=$ Ln Total Local Government Assets).

\subsection{Model Specification}

Formal testing to determine which model is better to use is based on statistical decisions. Statistically, three tests can be used to determine which method to choose. These are the Chow test (common effects vs fixed effects), the Hausman test (fixed effects vs random effects), and the Lagrange multiplier test (common effects vs random effects).

\subsection{Data Analysis Method}

The data analysis design is used to test the effect of the AIS and competence on the quality of FSLGs, with GGG as the moderating variable and performance as an intervening variable. The panel data equation models are as follows:

Equation I:

Q FSLG $=\mathrm{a}+\beta_{1}$ AIS $+\beta_{2}$ Comp $+\beta_{3}$ Per $+\beta_{4}$ Size $+\beta_{5}$ Loc $+\beta_{6} \mathrm{TP}+\mathrm{e}$

Per $=\mathrm{a}+\beta_{1}$ AIS $+\beta_{2}$ Comp $+\mathrm{e}$

$\mathrm{Q}$ FSLG $=\mathrm{a}+\beta_{1}$ AIS $+\beta_{2}$ Comp $+\beta_{3}$ AIS.GGG $+\beta_{4}$ Comp.GGG $+\mathrm{e}$

Equation II:

Q FSLG $=\mathrm{a}+\beta_{1}$ AIS $+\beta_{2}$ Comp $+\beta_{3}$ Per $+\beta_{4}$ Size $+\beta_{5}$ Loc $+\beta_{6}$ TP $+\beta_{7}$ AIS.GGG $+\beta_{8}$ Comp.GGG $+\mathrm{e}$

\section{Results and Discussion}

Based on the descriptive statistics in Table 6, the mean value of the quality of FSLGs is 34.3650 , indicating that the average quality of FSLGs is high.

The mean value for AIS is 0.9617, indicating that almost all local governments sampled in this research have successfully implemented their AIS. The mean value of competence is 0.9622 , which indicates that the competence of the civil state apparatus is high. The mean performance value is 0.9865 , which indicates that the overall performance of the CSA is good. The mean value of GGG is 0.9808, indicating that most of the samples used in the research have a good level of governance. The mean value of the quality of FSLGs, AIS, competence, performance, and GGG are greater than the standard deviation, indicating the distribution of small data variables and shows that the mean value can be used as a representation of all data.

Table 6. Descriptive statistics.

\begin{tabular}{l|c|c|c|c|c|c}
\hline Sample: 2015-2018 & Mean & Median & Maximum & Minimum & Std. deviation & Observations \\
\hline Quality of FSLGs & 34.3650 & 35.0000 & 36.0000 & 29.0000 & 1.5983 & 100 \\
\hline AIS & 0.9617 & 1.0000 & 1.6667 & 0.3455 & 0.1518 & 100 \\
\hline Competence & 0.9622 & 0.9981 & 2.2654 & 0.0750 & 0.2965 & 100 \\
\hline Performance & 0.9865 & 1.0000 & 1.8120 & 0.0528 & 0.1776 & 100 \\
\hline GGG & 0.9808 & 1.0000 & 2.4767 & 0.3100 & 0.2538 & 100 \\
\hline LG size & 29.1379 & 28.7514 & 33.8313 & 27.9324 & 1.2007 & 100 \\
\hline LG location & 1.2000 & 1.0000 & 2.0000 & 1.0000 & 0.4020 & 100 \\
\hline Total population & $1,711,413$ & 805,255 & $12,488,160$ & 126,578 & $2,900,278$ & 100 \\
\hline
\end{tabular}


Table 7. Sobel Test Results.

\begin{tabular}{l|c|c}
\hline Performance & Coefficient & SE \\
\hline AIS & 0.029075 & 0.119534 \\
\hline Competence & 0.190723 & 0.055145 \\
\hline FSLG quality & Coefficient & SE \\
\hline Performance & 0.292179 & 0.180411 \\
\hline & Sobel value & t-stat \\
\hline AIS -> Performance -> FSLG quality & 0.24 & 0.8099 \\
\hline Competence ->Performance -> FSLG quality & 1.446 & 0.142 \\
\hline
\end{tabular}

Based on Table 7, it can be concluded that performance is not able to mediate the effect of the AIS and competence on the quality of FSLGs.

This study tested the coefficient of determination, or the adjusted R-squared, to determine the percentage contribution of the independent variable to the dependent variable. From Table 8 , it can be seen that the adjusted R-squared value is over $10 \%$, so the model is considered adequate.

Table 8. Determination coefficient test results.

\begin{tabular}{|c|c|}
\hline R-squared & 0.128282 \\
\hline Adjusted R-squared & 0.110308 \\
\hline R-squared & 0.987825 \\
\hline Adjusted R-squared & 0.986086 \\
\hline
\end{tabular}

The results of the coefficient of determination show an adjusted R-squared value of 0.1103 for model 1 and 0.9860 for model 2 . It shows that the independent variables in total can explain variations and contribute to the dependent variable/performance by $11.03 \%$, and the quality of FSLGs is $98.60 \%$. The rest is explained by other variables outside the model.

\begin{tabular}{l|l}
\multicolumn{2}{c}{ Table 9. F Test Results. } \\
\hline F-statistic & 7.137236 \\
\hline Prob. (F-statistic) & 0.001283 \\
\hline F-statistic & 567.9538 \\
\hline Prob. (F-statistic) & 0.000000 \\
\hline
\end{tabular}

From Table 9, it can be seen that the $\mathrm{F}$ statistic and the probability value $=0.00<0.05$, so $\mathrm{H}_{0}$ is rejected and it is concluded that the model is fit, with an error rate of $5 \%$, meaning that the independent variables simultaneously affect performance and the quality of FSLGs.

Table 10. t-Test Results on the quality of FSLGs.

\begin{tabular}{l|c|c|c|l|l}
\hline Variable & Coefficient & t-statistic & Prob. & Decision & Conclusion \\
\hline AIS & 0.029075 & 0.243234 & 0.8083 & $\mathrm{H}_{0}$ failed to be rejected & Has no significant effect \\
\hline Competence & 0.190723 & 3.458578 & 0.0008 & $\mathrm{H}_{0}$ was rejected & Has a significant effect \\
\hline Performance & 0.292179 & 1.619520 & 0.1103 & $\mathrm{H}_{0}$ failed to be rejected & Has no significant effect \\
\hline LG size & 0.014007 & 4.316948 & 0.0001 & $\mathrm{H}_{0}$ was rejected & Has a significant effect \\
\hline LG location & 0.017029 & 1.252661 & 0.2150 & $\mathrm{H}_{0}$ failed to be rejected & Has no significant effect \\
\hline Total population & 0.006696 & 0.938685 & 0.3515 & $\mathrm{H}_{0}$ failed to be rejected & Has no significant effect \\
\hline
\end{tabular}

Table 11. t-Test results on performance.

\begin{tabular}{l|c|c|c|l|l}
\hline Variable & Coefficient & t-statistic & Prob. & Decision & Conclusion \\
\hline AIS & 0.08314 & 2.607184 & 0.0114 & $\mathrm{H}_{0}$ was rejected & Has a significant effect \\
\hline Competence & 0.079737 & 2.382792 & 0.0202 & $\mathrm{H}_{0}$ was rejected & Has a significant effect \\
\hline Table 12. T-test results on the quality of FSLG with GGG as the moderating variable. \\
\begin{tabular}{l|c|c|c|c|l}
\hline Variable \\
AIS_GGG
\end{tabular} & Coefficient & t-statistic & Prob. & Decision & Conclusion \\
\hline Competence_GGG & 0.028640 & 2.189793 & 0.0323 & $\mathrm{H}_{0}$ was rejected & Moderate \\
\hline
\end{tabular}

In Tables 10, 11, and 12 it can be seen that only competence has an effect on the quality of FSLGs and performance. Meanwhile, the AIS only affects performance. GGG as a moderating variable also strengthens the effect of AIS and competencies on the quality of FSLGs. This can be seen from the probability value, which is less than 0.05 .

Based on the statistical analysis of the first hypothesis $\left(\mathrm{H}_{1}\right)$, the AIS has no significant effect on the quality of FSLGs because the data shows that the achievement of local government performance related to the AIS 
has approached a maximum value of $100 \%$. The results for second hypothesis $\left(\mathrm{H}_{2}\right)$ show that competence has a positive effect on the quality of FSLGs, meaning that the higher the competence of civil state apparatus employees, the higher the quality of FSLGs will be. The results of the analysis relating to the third hypothesis $\left(\mathrm{H}_{3}\right)$ shows that the AIS has a positive effect on accepted performance because the use of the AIS will make it easier for civil state apparatus employees to carry out their duties, and it will have a positive impact on their performance. The fourth hypothesis $\left(\mathrm{H}_{4}\right)$ is accepted as competence was found to have a positive effect on performance. The results for the fifth hypothesis $\left(\mathrm{H}_{5}\right)$ show that performance does not have a significant effect on the quality of FSLGs because performance is already a requirement, so civil state apparatus employees will endeavor to carry out their duties properly. The sixth hypothesis $\left(\mathrm{H}_{6}\right)$ is accepted as it was confirmed that GGG strengthens the effect of the AIS on the quality of FSLGs. The seventh hypothesis $\left(\mathrm{H}_{7}\right)$, that $\mathrm{GGG}$ strengthens the effect of competence on the quality of FSLGs, is accepted because, with GGG, the competences of the civil state apparatus employees will be channeled efficiently.

This study tested the extent of the effect of indicators sourced from APRGEs in measuring the quality of FSLGs. The statistic test results show that AIS and performance do not affect the quality of FSLGs. However, AIS and performance can still be used to measure the quality of FSLGs. AIS is a primary need that cannot be left out in the process of presenting FSLGs. Also, the tabulated data results do not have high variance values, so if they are processed in statistics, it will show that it does not affect the dependent variable. Likewise, with performance, each local government already has its own KPIs, which ensure that civil state apparatus employees work efficiently and effectively and follow existing regulations, including in the preparation of FSLGs.

\section{Conclusion}

The measurement index of the quality of FSLGs (that comes from APRGEs, FSLG notes, and ICS) has been created successfully in this research, and it can be used to measure the quality of FSLGs produced by local governments. The index developed in this research contains FSLG quality assessment categories.

The limitations encountered in this study include the limited number of research objects, which comprises only 25 local governments. This means that the measurement index developed in this research can only be used to assess the quality of FSLGs. Another limitation is that the local governments still do not produce ICS reports. ICS reports should be submitted in the FSLG notes.

The implications of this research facilitate external parties in assessing the quality of FSLGs. Meanwhile, internal parties can facilitate the improvement of the quality of FSLGs or maintain it. Future research can increase the sample and extend the research period to achieve better results.

\section{References}

Andini, D., \& Yusrawati. (2015). The influence of human resource competence and the application of regional financial accounting systems on the quality of financial statement of local government. Journal of Economics, Management, and Accounting, 24(1), 65-82.

Armel, R., Nasir, A., \& Safitri, D. (2017). The influence of human resource competence, the application of government accounting standards, the use of information technology, and internal control systems on the quality of financial statement of local government (Study on the Dumai city regional work unit). Online Journal of Economics Faculty Students, 4(1), 105-119.

COSO. (2019). Approaching the 2013 framework implementation. In A. Schandl, \& P. L. Foster, COSO Internal Control Integrated Framework: An Implementation Guide for the Healthcare Provider Industry (pp. 7). America: COSOCROWE.

Efendi, L., Darwanis, D., \& Abdullah, S. (2017). Factors that affect the quality of financial statement of local government (Study on the work unit of Central Aceh Regency). Journal of Darussalam Economic Perspective, 3(2), 182-195.

Gafur, S., Yusuf, A., \& Lamaya, F. (2016). The effect of the use of regional financial accounting information systems on the quality of financial statement of local government with internal audit as an intervening variable. Journal of Accounting, 3(3), 37-49.

Hanifa, L., Wawo, A. B., \& Husin. (2016). The influence of the competence of financial managers and regional financial accounting systems on the quality of financial reports. Journal of Development Economics Progress, 1(2), 65-80.

Hendriyani, R., \& Tahar, A. (2015). The analysis of the factors that affect the level of disclosure of provincial government financial statements in Indonesia. Journal of Business and Economics, 22(1), 25-33.

Inapty, M. A. F. B. A., \& Martiningsih, R. S. P. (2016). The effect of applying government accounting standards, apparatus competence, and the role of internal audit on the quality of financial statement information. Journal of Accounting Science, 9(1), 27-42.

Jensen, M. C., \& Meckling, W. H. (1976). Theory of the firm: Managerial behavior, agency costs and ownership structure. Journal of Financial Economics, 3(4), 305-360.

Kewo, C. L., \& Rufaedah, Y. (2019). The effect of the implementation of good governance and the effectiveness of internal audits on the quality offinancial reports. Paper presented at the Industrial Research Workshop and National Seminar.

Kurniawan, I. S. (2016). Determinants of the quality of local government financial reports. Journal of Economics and Management, 13(1), 47-58.

Oktarina, M. (2016). The effect of the application of government accounting standards, the quality of local government apparatus, and good governance on the quality of financial reports in the city of Semarang (Case study on the financial management office of regional assets in the Semarang city in 2014). Journal of Accounting, 2(2), 1-15. 
Pandansari, T. (2016). The level of dependence, the complexity of the government, and the level of disclosure of local government financial statements. Journal of Economics and Business, 19(3), 463-485.

Putri, W. M., \& Arza, F. I. (2015). The analysis of the factors that affect the level of disclosure of financial statement of local government. Journal of Accounting, 4(32), 1-11.

Sihasale, D. C., \& Setiyowati, S. W. (2018). The effect of understanding government accounting standards and the use of accounting information systems on the quality of financial statement of local government with HR competence as a moderating variable. Accounting Student Research Journal, 6(1), 1-17.

Simon, Y., Mas' ud, M., \& Su'un, M. (2016). The role of apparatus competence, internal control system on good governance and the quality of financial statement information. Researchers World, 7(4), 123-132. https://doi.org/10.18843/rwjasc/v7i4/14

Spencer, L., \& Signe, M. S. (1993). Competence at work, models for superior performance. Canada: John Wiley \& Sons, Inc.

Suhardjanto, J., \& Yulianingtyas, R. R. (2010). The effect of local government characteristics on mandatory compliance in local government reports. Journal of Accounting \& Audit, 8(1), 30-42.

United Nations Development Programme. (2015). Discussion paper: Governance and development-UN system task team on the post 2015 UN development agenda. New York: One United Nations Plaza.

Untary, N. R., \& Ardiyanto, M. D. (2015). The influence of accounting information systems, internal control systems, and human resource competencies on the quality of regional financial reports with external factors as moderating. Journal of Accounting, 4(71), 1-12.

Waliyyani, G. M., \& Makhmud, A. (2015). The effect of government characteristics on the level of disclosure of local government financial statements in Indonesia. Accounting Analysis Journal, 4(2), 1-8.

Wibawa, K. A. S., Sinarwati, N. K., \& Yuniarta, G. A. (2017). Factors that affect the quality of financial statement of local government at the buleleng regency regional apparatus work unit. E-Journal of Education Ganesha University, $2(8), 1-12$.

Zarlin, E., \& Khairani, S. (2017). The influence of accounting information systems and employee performance on the quality of financial reports at the Banyuasin regency public works and spatial planning office. Journal of Accounting, 3(2), 1-15. 